\title{
Exploring the Utility of Compound-Specific Isotope Analysis for Assessing Ferrous Iron- Mediated Reduction of RDX in the Subsurface
}

Yiran Tong, ${ }^{\dagger}$ Matthew J. Berens, ${ }^{\dagger}$ Bridget A. Ulrich, ${ }^{{ }^{1}}$ Jakov Bolotin, ${ }^{\ddagger}$ Jennifer H. Strehlau, ${ }^{\dagger}$

Thomas B. Hofstetter ${ }^{\ddagger *}$; William A. Arnold ${ }^{+*}$

${ }^{\dagger}$ Department of Civil, Environmental, and Geo- Engineering, University of Minnesota, 500

Pillsbury Drive SE, Minneapolis, Minnesota 55455-0116, United States

${ }^{\ddagger}$ Eawag, Swiss Federal Institute of Aquatic Science and Technology, Department of

Environmental Chemistry, Überlandstrasse 133, CH-8600 Dübendorf, Switzerland

${ }^{1}$ Current address: Natural Resources Research Institute, University of Minnesota-Duluth, 5013

Miller Truck Highway, Duluth, MN 55811

*Corresponding authors: William A. Arnold; Phone: 612-625-8582; e-mail: arnol032@umn.edu, Thomas B. Hofstetter; phone: +41 5876550 76; email: thomas.hofstetter@eawag.ch 


\begin{abstract}
Subsurface contamination with the explosive hexahydro-1,3,5-trinitro-1,3,5-triazine (RDX) at ordnance production and testing sites is a problem because of the persistence, mobility, and toxicity of RDX and the formation of toxic products under anoxic conditions. While the utility of compound specific isotope analysis for inferring natural attenuation pathways from stable isotope ratios has been demonstrated, the stable isotope fractionation for RDX reduction by ironbearing minerals remains unknown. Here, the $\mathrm{N}$ isotope fractionation of RDX during reduction by $\mathrm{Fe}(\mathrm{II})$ associated with Fe minerals and natural sediments was evaluated and applied to the assessment of mineral-catalyzed RDX reduction in a contaminant plume and in sediment columns treated by in-situ chemical reduction. Laboratory studies revealed that RDX was reduced to nitroso compounds without denitration and the concomitant ring cleavage. $\mathrm{Fe}(\mathrm{II}) / \mathrm{iron}$ oxide mineral-catalyzed reactions exhibited $\mathrm{N}$ isotope enrichment factors, $\varepsilon_{\mathrm{N}}$, between $6.3 \pm 0.3 \%$ o to $-8.2 \pm 0.2 \%$ o corresponding to an apparent ${ }^{15} \mathrm{~N}$ kinetic isotope effect of $1.04-1.05$. The observed variations of the $\delta^{15} \mathrm{~N}$ of $\sim 15 \%$ in RDX from groundwater samples suggested an extent of reductive transformation of $85 \%$ at an ammunition plant. Conversely, we observed masking of $\mathrm{N}$ isotope fractionation after RDX reduction in laboratory flow-through systems, which was presumably due to a limited accessibility to reactive $\mathrm{Fe}(\mathrm{II})$.
\end{abstract}

\title{
TOC Art
}

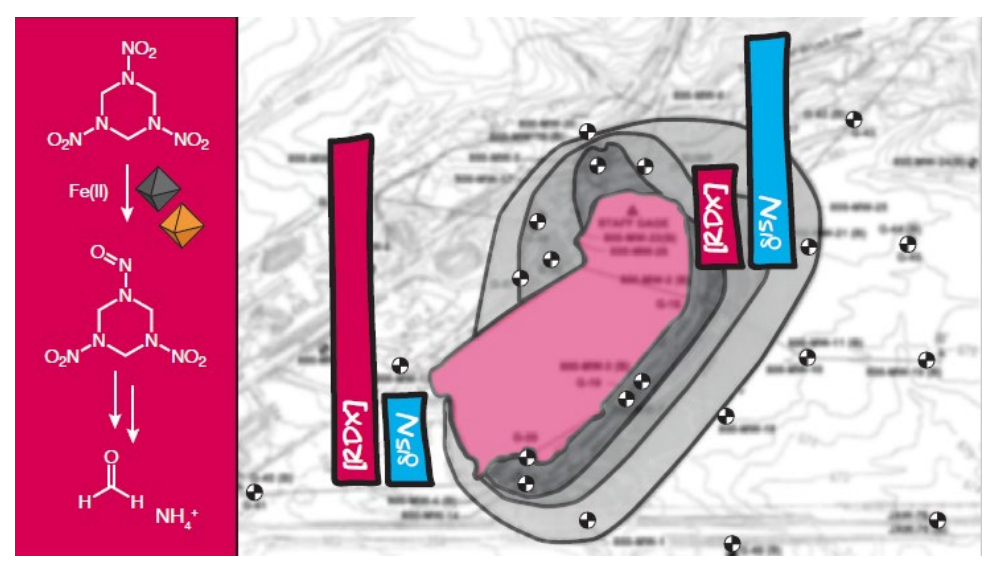




\section{Introduction}

The synthetic cyclic N-nitramine munition compound, hexahydro-1,3,5-trinitro-1,3,5-triazine (RDX), has been extensively used in military operations. ${ }^{1,2}$ RDX poses both chronic and acute toxicity threats to aquatic and terrestrial organisms and is considered a possible human carcinogen. ${ }^{3-5}$ The persistence, high solubility, and low volatility of RDX have led to widespread contamination in the subsurface ${ }^{6-9}$ namely in soil, sediment, and water at military training installations, production facilities, and munition disposal sites. ${ }^{10,11}$ Contamination problems are often aggravated under anoxic conditions through the formation of equally mobile nitroso intermediates, which are more toxic to some terrestrial biota than RDX. ${ }^{12,13}$ Due to the long timescales over which (bio)degradation of RDX occurs and complicating factors such as multiple contamination sources, dilution and sorption processes, and subsurface heterogeneity, the application of compound specific isotope analysis (CSIA) has been proposed for the assessment of RDX degradation in subsurface environments. ${ }^{14,15}$

CSIA is used to characterize changes to the stable isotope ratios of elements in nitro-containing munition compounds. ${ }^{14-20}$ These changes are associated with a particular (bio)chemical degradation pathway based on the assumption that kinetic isotope effects for the reacting bonds cause the observable stable isotope fractionation. ${ }^{16,19-25}$ For RDX, variations of ${ }^{15} \mathrm{~N} /{ }^{14} \mathrm{~N},{ }^{13} \mathrm{C} /{ }^{12} \mathrm{C}$, and ${ }^{18} \mathrm{O} /{ }^{16} \mathrm{O}$ have been associated with biodegradation under aerobic and anaerobic conditions and with abiotic alkaline hydrolysis reactions in both laboratory and field observations. ${ }^{14,15,17,18,26}$ Assignment of the initial bond cleavage reactions in RDX to the different transformation pathways, however, is particularly challenging regardless of whether transformation occurs biologically or abiotically. The first of two principal routes of RDX transformation, sequential 
reduction of $-\mathrm{NO}_{2}$ groups, leads to nitroso-products (Scheme 1, top row). The second route of transformation is denitration (Scheme 1, top row to second row), which can be initiated by reduction, oxidation, or deprotonation of $\mathrm{RDX}$ or nitroso intermediates. Denitration gives rise to transient intermediates, triggering the decomposition of RDX into small molecules including $\mathrm{NO}_{2}{ }^{-}, \mathrm{N}_{2} \mathrm{O}, \mathrm{NH}_{4}{ }^{+}, \mathrm{HCHO}$, and $\mathrm{HCOOH}$ (Scheme 1, second row). ${ }^{27}$

Anaerobic biodegradation of RDX typically leads to the sequential partial-nitro-group-reduction to nitroso intermediates (hexahydro-1-nitroso-3,5-dinitro-1,3,5-triazine (MNX, Scheme 1), 1,3dinitroso-5-nitro-1,3,5-triazine (DNX), and hexahydro-1,3,5-trinitroso-1,3,5-triazine (TNX). ${ }^{18,28}$ This process is accompanied by an $\mathrm{N}-\mathrm{O}$ bond cleavage that gives rise to substantial $\mathrm{N}$ isotope fractionation with $\mathrm{N}$ isotope enrichment factors, $\varepsilon_{\mathrm{N}}$, of $-4.7 \%$ to $-9.9 \%$, ${ }^{17}$ whereas $\mathrm{C}$ isotope enrichment factors, $\varepsilon_{\mathrm{C}}$, are much smaller $(-2.7 \%) .{ }^{17}$ An alternative anaerobic biodegradation pathway involves cleavage of the 1,3,5-triazine ring without formation of similarly large quantities of stable nitroso-intermediates, but with removal of nitrite in the denitration reaction. This causes even larger $\mathrm{N}$ isotope enrichment (-12\%o) which presumably reflects contributions of both $\mathrm{NO}_{2}$ reduction and denitration(Scheme 1). ${ }^{17,29}$ Biodegradation under aerobic conditions and alkaline hydrolysis pathways have both been suggested to denitrate RDX to a dinitro-1,3,5triazacyclohex-1-ene intermediate (3 in Scheme 1). ${ }^{17,18,26,27,30-32}$ While the enzymatic reaction involves an oxidation of the methylene carbon, the hydrolysis pathway proceeds as a basecatalyzed deprotonation and elimination of nitrite. These mechanistic differences are also manifested in distinct $\mathrm{C}$ and $\mathrm{N}$ isotope fractionation behavior, with $\varepsilon_{\mathrm{N}}$ between $-2.1 \%$ and $-2.4 \%$ as well as negligible $\varepsilon_{\mathrm{C}}$ for enzymatic oxidation vs. $\varepsilon_{\mathrm{N}}$ of $-7.8 \%$ and $\varepsilon_{\mathrm{C}}-5.3 \%$ for the $\mathrm{HNO}_{2}$ elimination. ${ }^{17,18,26}$ 
<smiles>[Y]C(C)CCN[N+](=O)[O-]</smiles>

Nitro group reduction<smiles>CC(C)O[N+](=O)[O-]</smiles>

Partial nitro group reduction / denitration<smiles></smiles>

$\mathrm{H}$-atom transfer / denitration<smiles>[2H]C1N(C2N(OC(C)C)CN([N+](=O)[O-])CN2[N+](=O)[O-])CN([N+](=O)[O-])CN1[N+](=O)[O-]</smiles>

Alkaline hydrolysis $\left(\mathrm{HNO}_{2}\right.$ elimination)<smiles>C[C@H](O)C1N([N+](=O)[O-])CN([N+](=O)[O-])CN1[N+](=O)[O-]</smiles><smiles>O=[N+]([O-])N1C=NCN([N+](=O)[O-])C1</smiles>

3

Scheme 1. Top: Principal routes of RDX transformation through sequential reduction to MNX (hexahydro-1-nitroso-3,5-dinitro-1,3,5-triazine), DNX (1,3-dinitroso-5-nitro-1,3,5-triazine), and TNX (hexahydro-1,3,5-trinitroso-1,3,5-triazine) vs. denitration/ ring cleavage of RDX (or nitroso-intermediates MNX, DNX, TNX) to intermediates including 4-nitro-2,4-diazabutanal (1) and methylenedinitramine (2), formaldehyde, nitrite, ammonia, and nitrous oxide. Bottom four rows: Initial reactions for RDX transformation through nitro group reduction to nitroso compounds and denitration routes initiated by partial nitro group reduction, oxidation $(\mathrm{H}$ atom transfer), and alkaline hydrolysis. ${ }^{27}$ 
Despite the isotopic elucidation of RDX transformation reactions as well as applications of CSIA to infer the extent of RDX degradation processes at contaminated sites, ${ }^{14,15,33}$ the role of abiotic, mineral-catalyzed reduction of RDX for CSIA has remained largely overlooked. In anoxic groundwater, RDX undergoes abiotic reduction mediated by Fe(II) associated with iron minerals, such as iron oxides, iron sulfides, and clay minerals, ${ }^{31,34,35}$ or Fe(II) produced via in situ redox manipulation. ${ }^{36}$ While nitro group reduction to form nitroso intermediates likely occurs in the anoxic subsurface, ${ }^{35}$ there is a lack of knowledge regarding $\mathrm{N}$ and $\mathrm{C}$ isotope enrichment factors to assess this degradation pathway. Previous applications of CSIA to assess RDX transformation in contaminated subsurface environments all focused exclusively on enzyme-catalyzed reactions. ${ }^{14,15,33}$ From a mechanistic perspective, it is also unclear if any isotope fractionation associated with $\mathrm{Fe}(\mathrm{II})$-catalyzed processes is caused by the reduction of the $\mathrm{NO}_{2}$ functional groups of nitramines, which would cause isotope effects comparable to the abiotic reduction of aromatic $\mathrm{NO}_{2}$ moieties. ${ }^{16,19,20,22,23,37-40}$ Alternatively, denitration and ring cleavage reactions could also contribute to observable stable isotope fractionation, as has been hypothesized for anaerobic RDX biodegradation. ${ }^{17}$

The goal of this work was to assess the utility of CSIA for evaluating abiotic reduction of RDX in anaerobic environments. We hypothesize that the mobility of RDX in the subsurface, its high reactivity towards reduction by mineral-bound Fe(II), and the large isotope effect associated with abiotic $\mathrm{NO}_{2}$ reductions favor the observation of substantial $\mathrm{N}$ isotope fractionation and thus provide a sensitive probe for quantifying abiotic RDX transformation. The specific objectives of this study were to (1) quantify stable isotope enrichment factors for RDX reduction under controlled laboratory conditions for different $\mathrm{Fe}(\mathrm{II}) / \mathrm{Fe}$ mineral combinations, including natural 
sediments, under a range of conditions, (2) assess the contribution of $-\mathrm{NO}_{2}$ group reduction vs. denitration to $\mathrm{N}$ isotope enrichment through a combination of isotopic analyses with a semiquantitative evaluation of reaction product formation, and (3) evaluate the diagnostic value of CSIA-based information for inferring the extent of abiotic RDX reduction. To assess the diagnostic value, we analyzed $\delta^{15} \mathrm{~N}$ trends of RDX in groundwater affected by a contaminant plume from the Iowa Army Ammunition Plant (IAAAP, Middletown, IA). In a second application, we used the CSIA-based approach to monitor RDX transformation in laboratory column reactors where reactive Fe(II) for RDX reduction was generated in situ through iron mineral reduction with dithionite. ${ }^{20,41}$

\section{Material and Methods}

\section{Materials}

The synthesis of RDX, sources of chemicals and synthetic minerals, and collection and processing of aquifer materials from the Twin Cities Army Ammunition Plant (TCAAP) and soils from Tinker Air Force Base (Tinker AFB) are provided in the Supporting Information (SI).

\section{Batch experiments for evaluating $R D X$ reduction kinetics}

All batch experiments were conducted on an end-over-end rotator (Glas-Col) inside an anaerobic glove bag (Coy) with an atmosphere of $\mathrm{N}_{2}(97 \%) / \mathrm{H}_{2}(3 \%)$. Serum bottles $(36 \mathrm{~mL})$ containing 35 $\mathrm{mL}$ of deoxygenated (sparged $1 \mathrm{~h}$ per $\mathrm{L}$ with $99.99 \% \mathrm{~N}_{2}$; Matheson) ultrapure water (MilliporeSigma, $18.2 \mathrm{M} \Omega \cdot \mathrm{cm}$ ), to which the desired minerals and $10 \mathrm{mM} \mathrm{NaHCO}_{3}$ (to represent the buffer present in groundwater) were added, were prepared in a glove bag. Mineral loadings were $0.5 \mathrm{~g} / \mathrm{L}$ for goethite, $5 \mathrm{~g} / \mathrm{L}$ for green rust, $0.5 \mathrm{~g} / \mathrm{L}$ for hematite, $2 \mathrm{~g} / \mathrm{L}$ for magnetite, $0.45 \mathrm{~g} / \mathrm{L}$ 
for FeS. Mineral loadings were selected in preliminary experiments to obtain the desired extent of reaction in 2-8 hours. The $\mathrm{pH}$ of the solution was adjusted to $6.5,7.0$, or 7.5 using $\mathrm{HCl}$ or $\mathrm{NaOH}$. For synthetic $\mathrm{Fe}$ (III) minerals (goethite and hematite), the mixed-valent mineral (magnetite), and natural materials (TCAAP sediment and TAFB soil), $1 \mathrm{mM}$ aqueous $\mathrm{FeCl}_{2}$ was initially supplied in the solution to generate reduction equivalents as $\mathrm{Fe}(\mathrm{II}) /$ mineral associations. ${ }^{35,42}$ For FeS and green rust, no aqueous Fe(II) was added. The reactors were mixed and rotated at $40 \mathrm{rpm}$ either for $24 \mathrm{~h}$ (goethite, magnetite, and hematite, and the natural materials with the $\mathrm{Fe}(\mathrm{II}))$ or $1 \mathrm{~h}(\mathrm{FeS}$ and green rust) prior to initiation of RDX reduction. The amount of $\mathrm{Fe}(\mathrm{II})$ adsorbed to the Fe minerals was determined by the difference of the Fe(II) aqueous concentration before and after $24 \mathrm{~h}$ equilibration. Reactions were started by adding aliquots from a methanolic RDX stock solution to obtain an initial concentration of $250 \pm 50 \mu \mathrm{M}$. To quantify the kinetics of RDX reduction, $0.5 \mathrm{~mL}$ samples were withdrawn from the reactors at selected time intervals, and the suspensions were filtered through $0.2 \mu \mathrm{m}$ PTFE syringe filters into $2 \mathrm{~mL}$ amber vials. At each sampling interval, the aqueous Fe(II) concentration was measured by analyzing $0.1 \mathrm{~mL}$ of the filtered aliquot with the ferrozine method. ${ }^{43}$ Except for FeS and green rust suspensions, the $\mathrm{Fe}(\mathrm{II})$ concentration in each reactor was readjusted to $1 \mathrm{mM}$ by adding $\mathrm{FeCl}_{2}$ from an aqueous stock solution. The $\mathrm{pH}$ of each reaction solution was also readjusted to the initial value of $6.5,7$, or 7.5 with $\mathrm{NaOH}$ or $\mathrm{HCl} .^{42}$ All laboratory reduction experiments were run in duplicate. A set of experiments was performed with $20 \mu \mathrm{M}$ of TNX under the same reaction conditions using $\mathrm{Fe}(\mathrm{II}) /$ goethite, $\mathrm{Fe}(\mathrm{II}) /$ magnetite, and green rust.

Batch reactors for product analysis and CSIA 
To identify reaction products from RDX reduction, eight replicate reactors were prepared with $\mathrm{Fe}(\mathrm{II}) /$ goethite ( $\mathrm{pH}$ 6.5, 7.0, and 7.5), $\mathrm{Fe}(\mathrm{II}) /$ magnetite ( $\mathrm{pH} 7.5)$, green rust ( $\mathrm{pH} 7.5)$, and $\mathrm{FeS}$ ( $\mathrm{pH}$ 6.5, 7.0, and 7.5) using the procedures above. At each sampling time, a reactor was sacrificed through filtration of $20 \mathrm{~mL}$ of the reactor contents followed by acidification of filtrate to $\mathrm{pH}<4$ with $0.2 \mathrm{~mL}$ of $1 \mathrm{M} \mathrm{HCl}$ (trace metals purity) for the analysis of $\mathrm{RDX}$, nitroso intermediates, $\mathrm{HCHO}$, and $\mathrm{NH}_{4}{ }^{+}$.

Samples for CSIA of RDX were prepared in sets of eight replicate reactors that were sacrificed at different time points. One additional set of reactors for the $\mathrm{Fe}(\mathrm{II}) /$ goethite system at $\mathrm{pH} 7.5$ was used to evaluate effects of natural organic matter on RDX isotope fractionation to which Elliot Soil Humic Acid (ESHA) was added to $10 \mathrm{mg}-\mathrm{C} / \mathrm{L}$ together with the Fe(II). After filtering and acidifying the contents of each reactor, a subsample was taken to measure the remaining RDX concentration by HPLC. The remaining volume of filtered, acidified samples was then extracted via solid phase extraction (SPE) ${ }^{17}$ Briefly, Supelclean ${ }^{\mathrm{TM}}$ ENVI-Chrom SPE cartridges (Sigma Aldrich) were conditioned sequentially with $3 \mathrm{~mL}$ of ethyl acetate, methanol, and ultrapure water prior to loading $20 \mathrm{~mL}$ of sample onto each cartridge by gravity. The cartridges were then vacuum-dried and eluted with two $3 \mathrm{~mL}$ portions of ethyl acetate, such that minimal water was present in the eluent. Samples were then dried with sodium sulfate, filtered with Teflon syringe filters $(0.2 \mu \mathrm{m})$, and evaporated to $0.2 \mathrm{~mL}$ for stable isotope analyses.

\section{Extraction of groundwater samples and preparation for CSIA}

Seven groundwater samples (Figure S1) were collected from monitoring wells along a subsurface plume at the Line 800 site of the Iowa Army Ammunition Plant (IAAAP, 
Middletown, IA). Each sample contained approximately $4 \mathrm{~L}$ of groundwater. Details of the well locations, sampling method, and water chemistry are described in the SI (Section S2). Concentrations of RDX and the nitroso intermediates measured via gas chromatography-mass spectrometry from separate samples collected at the same time were provided by Jacobs Engineering Group (Table S1). SPE in preparation for isotope analysis was performed as described above, except the sample from each well was split into three $\sim 1.3 \mathrm{~L}$ portions that were passed through a separate SPE cartridge. After elution, the three extracts were combined and processed as described below.

\section{Reduction of RDX via in situ chemical reduction (ISCR) of a sediment packed column}

The column setup and ISCR procedure followed the protocols of Berens et al. ${ }^{20}$ Briefly, a borosilicate glass column (Kimble FLEX-COLUMNS®, I.D. $2.5 \mathrm{~cm}$ ) was wet-packed with 4.8 cm ( 39 g) of TCAAP sediment inside an anaerobic glove box. A flow adapter (Kimble CHROMAFLEX ${ }^{\circledR}$, I.D. $2.5 \mathrm{~cm}$ ) was secured to the end of the column to prevent sediment migration and leaching. The column was then saturated with a $10 \mathrm{mM} \mathrm{NaCl}$ solution to evaluate the total pore volume, porosity, density, and other physical properties of the column (Table S2). To minimize particle release/transport during the column experiments, the ionic strength of all further feed solutions was adjusted by adding $10 \mathrm{mM} \mathrm{NaCl} .{ }^{20} \mathrm{~A}$ sequence of three experiments at constant volumetric flow of $0.5 \mathrm{~mL} / \mathrm{min}$ was conducted unless indicated otherwise. First, a 0.115 $\mathrm{M} \mathrm{NaBr}$ tracer solution was introduced in a step input to determine hydraulic properties of the column (Table S2). Tracer concentrations were measured with a bromide ion selective electrode (Thermo Scientific Orion) after a 3-fold dilution of the samples. Thereafter, the column was conditioned with $10 \mathrm{mM} \mathrm{NaHCO}_{3}$ buffer for 10 pore volumes to remove the residual $\mathrm{NaBr}$. The 
second experiment consisted of an RDX pulse from a $500 \mathrm{~mL}$ reservoir with $200 \mu \mathrm{M}$ of RDX in $10 \mathrm{mM} \mathrm{NaHCO}_{3}$ buffer at $\mathrm{pH}$ 7.5. The breakthrough of RDX through the column with untreated aquifer material was used to determine the extent of RDX sorption in the column. After flushing the column with $\mathrm{NaHCO}_{3}$ buffer for 10 pore volumes, the TCAAP sediment ( $3.0 \%$ total iron) was then reduced by feeding a combined solution of $5.5 \mathrm{mM} \mathrm{Na}_{2} \mathrm{~S}_{2} \mathrm{O}_{4}$ and $22.2 \mathrm{mM} \mathrm{K}_{2} \mathrm{CO}_{3}$ into the column at $0.25 \mathrm{~mL} / \mathrm{min}$ for $\sim 18$ hours. The exact duration of $\mathrm{Na}_{2} \mathrm{~S}_{2} \mathrm{O}_{4}$ input during each reduction cycle was selected to target a reduction of one-tenth of the total iron content. This was determined using eq 1 which shows that 2 mols of Fe(II) are generated by every $1 \mathrm{~mol}$ of $\mathrm{S}_{2} \mathrm{O}_{4}{ }^{2-}$.

$$
\mathrm{S}_{2} \mathrm{O}_{4}^{2-}+2 \mathrm{Fe}^{3+}+2 \mathrm{H}_{2} \mathrm{O} \rightarrow 2 \mathrm{Fe}^{2+}+2 \mathrm{SO}_{3}^{2-}+4 \mathrm{H}^{+}
$$

As shown previously by Berens et al. ${ }^{20}$ changes of hydraulic properties after dithionite treatment were smaller than variations of porosities and dispersion coefficients among different columns, and iron reduction was incomplete either due to inaccessibility or reactivity constraints. In the third series of experiments, three pulses of $\mathrm{RDX}(210 \mu \mathrm{M}, 36$ pore volumes) were delivered to the column followed by $\sim 10$ pore volumes of $\mathrm{NaHCO}_{3}$ buffer to remove any residual $\mathrm{RDX}$ and then $\mathrm{Na}_{2} \mathrm{~S}_{2} \mathrm{O}_{4}$ and $\mathrm{K}_{2} \mathrm{CO}_{3}$ to re-reduce the $\mathrm{Fe}$ in between each of the cycles.

Column effluent for RDX concentration and stable isotope analysis was collected into test tubes every 0.6 pore volumes using a Bio-rad fraction collector. The sample collection was terminated when effluent RDX concentration attained the influent values or remained constant. The samples were immediately capped for quantification of RDX and nitroso intermediates. For RDX isotope ratio measurements, four consecutive samples were combined to generate sufficient volume (20 $\mathrm{mL}$ ). The combined samples were re-analyzed to determine the RDX and then processed by SPE as described above. 


\section{Analytical methods}

Aqueous concentrations of RDX, MNX, DNX, TNX were measured by high pressure liquid chromatography (HPLC) with UV-detection (details in Section S3). ${ }^{42}$ Formaldehyde ${ }^{44}$ and ammonium ${ }^{45}$ were quantified after derivatization by liquid chromatography with UV and fluorescence measurement, respectively (Section S3).

${ }^{15} \mathrm{~N} /{ }^{14} \mathrm{~N}$ ratios of RDX were determined by large volume injection coupled to gas chromatography isotope ratio mass spectrometry (GC/IRMS) consisting of a Trace GC and a Delta V IRMS (Thermo Scientific). Analyses followed procedures established previously ${ }^{17,19,26}$ and instrumental parameters are given in the SI. Method quantification limits were derived with the moving mean approach ${ }^{46}$ and corresponded to injection of $3 \mathrm{nmol} \mathrm{N}$ (Figure S2a, details in $\mathrm{SI})$. The $\delta^{15} \mathrm{~N}$ of RDX agreed well with typical $\mathrm{N}$ isotope signatures determined for RDX from different manufacturers and from various type of explosives. ${ }^{47}$

Measurement of ${ }^{13} \mathrm{C} /{ }^{12} \mathrm{C}$ ratios was strongly amplitude-dependent and did not allow for an accurate determination of $\delta^{13} \mathrm{C}$ for RDX with our standard material (Figure S2b). Due to this finding as well as the observation of chromatographic interferences of unknown, carboncontaining compounds in samples from RDX reduction experiments and in field samples, no $\delta^{13} \mathrm{C}$ are reported here.

\section{Analysis of reaction kinetics and predominant $R D X$ reaction pathways}

Pseudo-first order rate constants of RDX degradation were determined by linear regression of $\ln \left(\mathrm{c} / \mathrm{c}_{0}\right)$ vs. time $(\mathrm{t})$ for initial experiments, and non-linear fitting when considering RDX degradation and formation/decay of intermediates and products. Reported errors are $95 \%$ 
confidence limits propagated from the errors associated with duplicate regressed rate constants. Reaction pathways of RDX were assessed on a carbon mass basis to account for any formation of denitration/ring cleavage products during the reduction of RDX (Schemes 1). ${ }^{31}$ Concentrations of the carbon-containing analytes RDX, MNX, DNX, TNX, and formaldehyde, as well as a hypothetical C-containing product (C-Unidentified) were used to quantify losses of total C as the reduction of RDX proceeded. The model was expressed as sets of differential equations, with different sets of equations used to test whether ring cleavage occurred in RDX or the nitroso compounds (Section S4). The assumption was used that all reactions followed pseudo-first order kinetics, with reductant concentration being constant. Differential equations were solved in MATLAB (MathWorks, Version 9.5) using the initial C-based concentration of RDX (C-RDX) and fit to experimental data via a least-squares regression.

\section{Modeling RDX reactive transport in dithionite-treated sediment columns}

Simulations of RDX and Fe(II) concentrations in sediment columns were performed with Aquasim (Version 2.0) using the saturated soil-column compartment. ${ }^{48}$ Model parameters for the different series of experiments are listed in Tables S2 and S3 (Section S5). Sediment porosity and dispersivity were determined from the $\mathrm{NaBr}$ tracer experiment. Sorption of $\mathrm{RDX}$ to sediment column material was quantified based on its retardation relative to the non-sorbing $\mathrm{NaBr}$ tracer assuming linear sorption behavior and instantaneous localized sorption equilibrium according to eqs. 2 and 3 ,

$$
\begin{gathered}
\frac{d[R D X]_{s}}{d t}=-k_{\text {sorption }} \cdot\left([R D X]_{s, e q}-[R D X]_{S}\right) \\
K_{d}=\frac{[R D X]_{s, e q}}{[R D X]_{a q}}
\end{gathered}
$$


where $k_{\text {sorption }}$ is the rate constant of the adsorption process, and $[\mathrm{RDX}]_{\mathrm{s}, \mathrm{eq}}$ and $[\mathrm{RDX}]_{\mathrm{aq}}$ are the concentration of adsorbed RDX in equilibrium and aqueous, dissolved species, respectively. $K_{d}$ is the equilibrium sorption coefficient of RDX. RDX reduction by $\mathrm{Fe}(\mathrm{II})$ in sediment columns after ISCR was assessed with eqs. 4 and 5,

$$
\begin{gathered}
\frac{d[R D X]_{a q}}{d t}=-v_{R D X} \cdot k_{r e d} \cdot[R D X]_{a q} \cdot\left[F e^{I I}\right]_{s} \\
\frac{d\left[F e^{I I}\right]_{s}}{d t}=-v_{\text {red-equiv }} \cdot k_{\text {red }} \cdot[R D X]_{a q} \cdot\left[F e^{I I}\right]
\end{gathered}
$$

where $v_{\mathrm{RDX}}$ is the solid-water ratio used for conversion of sorbed to aqueous concentrations, and $k_{\text {red }}$ is the apparent RDX reduction and $\mathrm{Fe}(\mathrm{II})$ oxidation rate constant. The $v_{\text {red-equiv }}$ parameter describes the amount of $\mathrm{Fe}(\mathrm{II})$ oxidized per amount of RDX reduced and was also used for a qualitative assessment of $\mathrm{Fe}(\mathrm{II})$ availability for reductive RDX transformation after ISCR treatment, and the consequences thereof for the $\mathrm{N}$ isotope fractionation of $\mathrm{RDX}$.

\section{Analysis of CSIA data}

Nitrogen isotope enrichment factors, $\varepsilon_{\mathrm{N}}$, in batch reactor experiments were evaluated according to the methods described by Pati et al. ${ }^{21}$ from the natural log-linearized form of the correlation between measured isotope ratio and the fraction of remaining RDX. Apparent ${ }^{15} \mathrm{~N}$-kinetic isotope effects $\left({ }^{15} \mathrm{~N}\right.$-AKIE) were derived from $\varepsilon_{\mathrm{N}}$ by accounting for the 6-fold isotopic dilution caused by the $6 \mathrm{~N}$ atoms in RDX. The fractional extent of RDX transformation, $F$, during abiotic reduction at the Line 800 site of the IAAAP was calculated with eq. 6 , where $\delta^{15} \mathrm{~N}_{\mathrm{x}}$ and $\delta^{15} \mathrm{~N}_{0}$ are the RDX N isotope signatures measured at sampling locations $x$ and at the operationally defined contamination source. 


$$
F=1-\left(\frac{\delta^{15} N_{x}+1}{\delta^{15} N_{0}+1}\right)^{1 / \varepsilon_{N}}
$$

Values of $\delta^{15} \mathrm{~N}$ during experiments in dithionite-treated sediment columns were also evaluated for possible ${ }^{15} \mathrm{~N}$ isotope effects.

\section{Results and Discussion}

\section{Kinetics and Pathways of RDX reduction}

RDX was reduced in all of the tested suspensions as depicted in Figure 1a for Fe(II)/goethite at pH 7 and Figure S3 for Fe(II)/goethite, Fe(II)/magnetite, green rust, and FeS. The pseudo-first order rate constants for RDX reduction by iron minerals in the initial batch experiments are listed in Tables S4 (RDX) and S5 (TNX), and those from the experiments to evaluate product formation are in Table S6. The results are similar, and any differences were attributed to the linear vs non-linear fitting and experimental error. Consistent with past results, ${ }^{35,49,50}$ reaction rates increased with increasing solution $\mathrm{pH}$ for all minerals tested. Fe(II)/goethite rate constants were $0.13 \pm 0.03,0.38 \pm 0.16$, and $1.24 \pm 0.28 \mathrm{~h}^{-1}$ at $\mathrm{pH} 6.5,7$, and 7.5, respectively (Table S6), consistent with increased adsorption of Fe(II) on the iron (oxy)hydroxides (the adsorption of $\mathrm{Fe}$ (II) by goethite was $0.15 \pm 0.07,0.28 \pm 0.08,0.39 \pm 0.07 \mathrm{mmol} \mathrm{Fe}(\mathrm{II}) / \mathrm{g}$ goethite at $\mathrm{pH} 6.5,7$, and 7.5) and more favorable reduction potentials for $\mathrm{Fe}(\mathrm{II}) /$ mineral systems with increasing $\mathrm{pH}^{49}$

Previously, no degradation of RDX or DNAN by TCAAP sediment (containing predominantly magnetite, 3.03\%-wt Fe) was observed in the absence of aqueous Fe(II). ${ }^{20,42}$ Thus, aqueous $\mathrm{Fe}(\mathrm{II})$ was constantly supplied to TAFB (containing predominantly hematite, $2.44 \%$-wt Fe) and TCAAP reactors in the same manner as for synthetic materials. The lower rate constants 
observed at similar or greater iron mineral loadings for these materials (Table S4) suggests the formation of $\mathrm{Fe}(\mathrm{II})$ associations with less reactive minerals than iron oxides (e.g., silicates). ${ }^{42,51}$
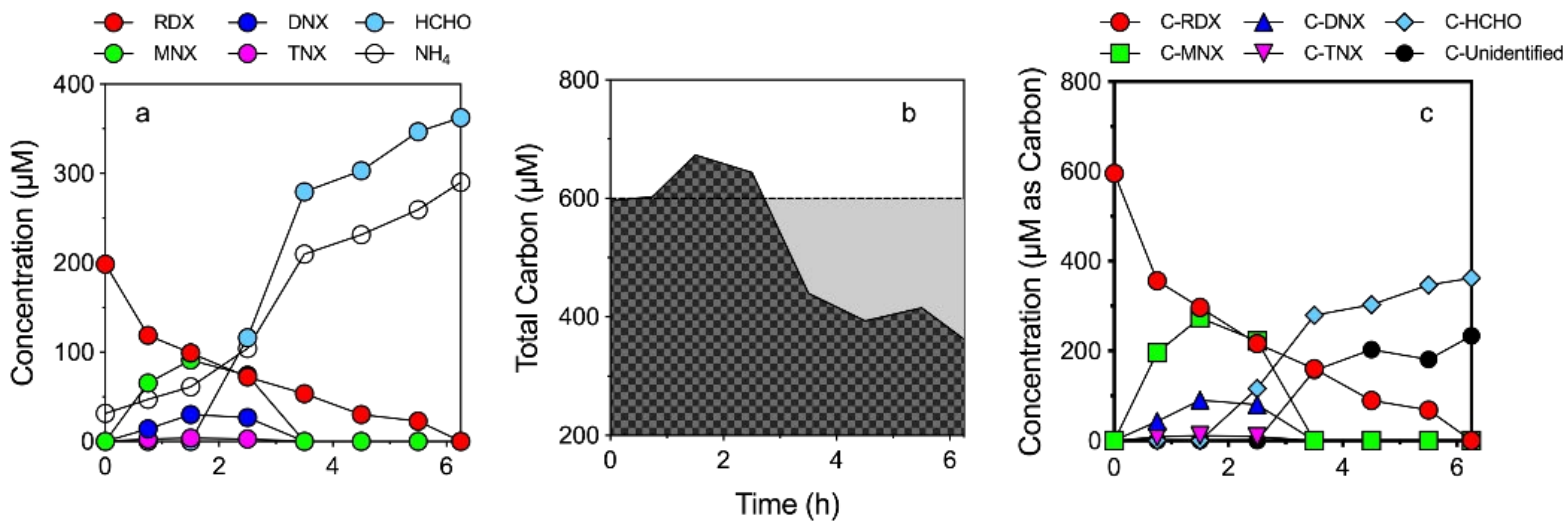

Figure 1. Concentration versus time data for RDX, intermediates, and end products during abiotic $\mathrm{RDX}$ reduction in the $\mathrm{Fe}(\mathrm{II}) /$ goethite reactors at $\mathrm{pH} 7$. (a) Measured concentrations of RDX, nitroso intermediates and final degradation products, (b) total carbon mass balance (initial $\mathrm{C}$ from $\mathrm{RDX}=600 \mu \mathrm{M}$ ), (c) concentration of RDX, nitroso intermediates, and products plotted in $\mu \mathrm{M}$ as carbon (denoted as C-compound). A hypothetical carbon-containing product (C-Unidentified; black solid circle) was introduced to compensate for the incomplete carbon mass balance and was assumed to be a single reaction product in kinetic fitting.

Different minerals can react with RDX through different and/or multiple transformation pathways (Scheme 1). An interpretation of the observable stable isotope fractionation (see below) thus requires an assessment of the principal pathways. For all minerals tested, MNX, DNX, and TNX were observed, indicating reduction of the nitro groups on RDX. Additionally, RDX and/or the nitroso compounds must be reacting via ring cleavage, given the formation of $\mathrm{HCHO}$ and a decreasing overall carbon mass balance (Figures 1 and S3). The molar mass balance for each experimental system was converted to a carbon-based mass balance as illustrated in Figure 1b for Fe(II)/goethite at $\mathrm{pH}$ 7. C-Unidentified was considered as a single, final product because carbon deficits began during late stages of the reaction (Figure $1 \mathrm{~b}$ ) and CUnidentified and HCHO appear in parallel. Methylenedinitramine (2 in Scheme 1) is unlikely 
responsible for the carbon deficit because it undergoes instantaneous transformation to nitramine, $\mathrm{HCHO}, \mathrm{N}_{2} \mathrm{O}$, and $\mathrm{NH}_{4}{ }^{+}$under anaerobic conditions. ${ }^{31} \mathrm{C}$-Unidentified could be one or more carbon-containing products, but from the prospective pathways, this portion of the mass is an end-product.

Based on the concentration of carbon-containing species during batch experiments (Figures 1 and S3), potential reaction pathways were tested through kinetic modeling using the equations in Section S4 with the assumption that the nitroso intermediates were sequentially produced $(\mathrm{RDX} \rightarrow \mathrm{MNX} \rightarrow \mathrm{DNX} \rightarrow \mathrm{TNX})$. The differences among the potential reaction pathways (Section S6) were the species from which $\mathrm{C}-\mathrm{HCHO}$ and $\mathrm{C}$-Unidentified were formed. The formation of these final products was considered to occur from RDX, one of the nitroso compounds, or a combination thereof. The experimental data and the rate constants given by the model with the lowest normalized residuals for the tested $\mathrm{pH} /$ mineral combinations are summarized in Figure $\mathrm{S} 3$ and Table S6. For Fe(II)/goethite systems, reactions of MNX, DNX, and TNX were more rapid than reaction of RDX. As illustrated in Table S6, the rate constants for the transformation of DNX to both HCHO and C-Unidentified were twice as high as those for RDX or MNX. This modeling outcome is consistent with the limited observed accumulation of transient MNX, DNX, and TNX species. The delayed formation of $\mathrm{HCHO}$ and C-Unidentified (Figure 1c) indicates these ring cleavage products form from the nitroso intermediates. For the iron oxides, the data are best fit by Scheme S1a (Tables S6-S8), where HCHO and C-Unidentified are formed from DNX and/or TNX. For FeS, the slower degradation of MNX and accumulation of DNX and TNX resulted in the best fit if ring cleavage of RDX and/or MNX to form $\mathrm{HCHO}$ and $\mathrm{C}$ Unidentified were included in the kinetic model (Scheme S1b; Tables S6 and S9). 
The goodness of fit for other proposed pathways for the iron oxides and FeS, which had substantially higher residuals, is shown in Tables S7-S9. The results indicate that for the iron oxides, the slowest reaction during the sequential transformation of RDX to TNX is to the formation of MNX from RDX. Moreover, the reaction of RDX only occurs via nitro group reduction, allowing for a mechanistic interpretation of the RDX CSIA results. For FeS, RDX appears to react via a combination of reduction and dinitration/ring cleavage. The slower reaction of the nitroso compounds with FeS leads to their accumulation and affects isotopic analyses (see below).

\section{$R D X$ reduction evaluated by CSIA}

Nitrogen isotope fractionation during RDX reduction was assessed for each iron mineral suspension. As shown in Figure 2 and Table 1, the extent of $\mathrm{N}$ isotope fractionation was large (up to $30 \%$ ) and the $\mathrm{N}$ isotope enrichment factors, $\varepsilon_{\mathrm{N}}$, were confined to values between $-6.3 \pm 0.3 \%$ and $-8.1 \pm 0.2 \%$. Small changes of $\mathrm{pH}$ by 0.5 units or the presence of organic matter did not lead to changes of $\mathrm{N}$ isotope fractionation in RDX. The identical behavior was observed for Fe(II)-amended TCAAP sediment and TAFB soil $\left(\varepsilon_{\mathrm{N}}=-8 \%\right)$ implying the same abiotic reduction reaction of RDX by mineral associated $\mathrm{Fe}(\mathrm{II})$ in all batch experiments. Initial analyses showed that the nitroso intermediates were also retained by SPE and co-eluted with RDX on the GC column, thus introducing interferences to the instrumental signal. Thus, experiments with $\mathrm{Fe}(\mathrm{II}) /$ goethite at $\mathrm{pH} 6.5$ and with $\mathrm{FeS}$ were not included. As a consequence, we were also not able to gather additional insights into Scheme S1b by CSIA from reactors containing FeS. 


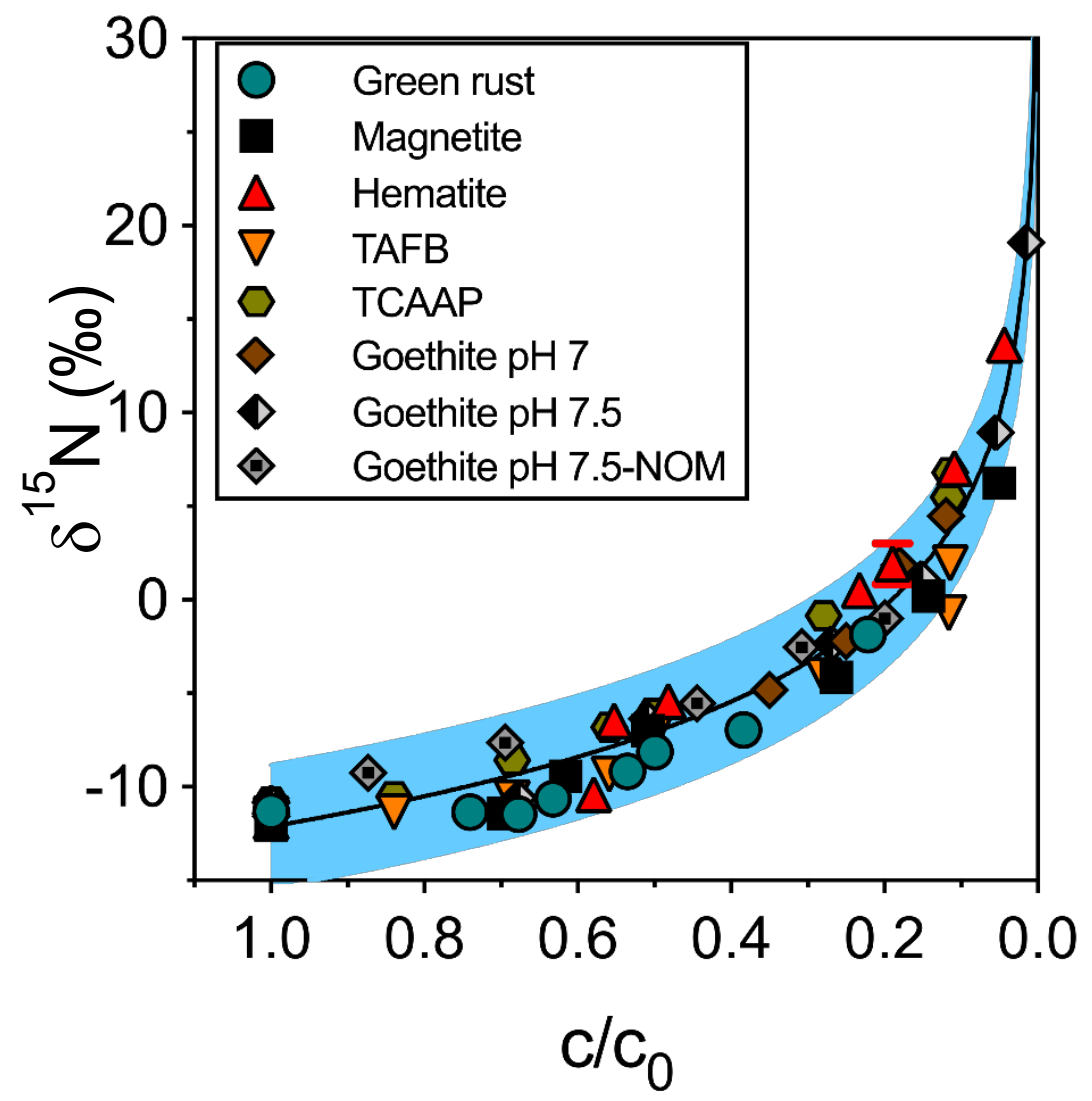

Figure 2. Nitrogen isotope signatures, $\delta^{15} \mathrm{~N}$, versus fraction of unreacted RDX $\left(\mathrm{c} / \mathrm{c}_{0}\right)$ determined in experiments with various Fe(II) containing suspensions. The goethite data represent experiments with $\mathrm{Fe}(\mathrm{II}) /$ goethite at $\mathrm{pH} 7.0$ and $\mathrm{pH} 7.5$, and $\mathrm{Fe}(\mathrm{II}) /$ goethite with ESHA at $\mathrm{pH} 7.5$, and all other experiments were carried out at $\mathrm{pH}$ 7.5. The curve was fit using the data from each set of conditions to obtain a single $\varepsilon_{\mathrm{N}}$ value of $-7.4 \pm 0.2 \%$ (individual values in Table 1). The error band shows the $95 \%$ confidence interval.

Similar $\varepsilon_{\mathrm{N}^{-}}$-values of $-9.9 \pm 0.7 \%$ were reported for anaerobic RDX biodegradation that was initiated by reduction of a $\mathrm{NO}_{2}$ moiety, ${ }^{17}$ whereas other biological and abiotic transformations of RDX under aerobic conditions, such as denitration or alkaline hydrolysis, led to much smaller $\varepsilon_{\mathrm{N}-v a l u e s}$ (Figure S4, Scheme 1). ${ }^{17,18,26,28}$ Based on the investigation of different anaerobic biotransformation pathways, Fuller et al. ${ }^{17}$ hypothesized that $\mathrm{N}$ isotope fractionation is even larger if denitration and concomitant ring-cleavage reactions were responsible for RDX disappearance. In this interpretation, bond-cleavage reactions would generate cyclic nitramine- $\mathrm{N}$ 
species and give rise to stronger $\mathrm{N}$ isotope fractionation with $\varepsilon_{\mathrm{N}}$-values as negative as $-12 \%$.

Considering the slightly less negative $\varepsilon_{N}$ shown in Table 1 , these findings indirectly confirm the interpretation that the initial steps of $\mathrm{Fe}(\mathrm{II})$-catalyzed reduction of RDX are confined to reduction of the $\mathrm{NO}_{2}$ moiety. This interpretation explained the observed ${ }^{15} \mathrm{~N}-\mathrm{AKIE}$ values were between 1.039 and 1.051 for this reaction. These isotope effects are approximately $20 \%$ larger than most of those reported for the reduction of nitroaromatic compounds studied in identical experimental systems $\left({ }^{15} \mathrm{~N} \text {-AKIEs }<1.040\right)^{19}$ as well as by other abiotic reductants ${ }^{16,39,40}$ even though ${ }^{15} \mathrm{~N}-$ AKIEs of 1.048 were also found for aromatic $\mathrm{NO}_{2}$ reduction by stoichiometric magnetite. ${ }^{38}$ Our data set adds to previous observations ${ }^{17}$ that the AKIEs for reduction of $\mathrm{NO}_{2}$ moieties of cyclic nitramines may exceed those of aromatic $\mathrm{NO}_{2}$ groups.

Table 1. Bulk $N$ isotope enrichment factors $\varepsilon_{N}$ and $\varepsilon_{C}$ during abiotic reduction, biodegradation, and hydrolysis of RDX

\begin{tabular}{|c|c|c|c|c|}
\hline Mineral & $\varepsilon_{N}^{\mathrm{a}}(\%)$ & ${ }^{15} \mathbf{N}-A K I E(-)$ & $\varepsilon^{\mathrm{a}}(\%)$ & ${ }^{13}$ C-AKIE (-) \\
\hline Green rust & $-6.9 \pm 0.8$ & $1.043 \pm 0.005$ & $\mathrm{ND}^{\mathrm{b}}$ & ND \\
\hline Hematite & $-8.1 \pm 0.2$ & $1.051 \pm 0.001$ & ND & ND \\
\hline Magnetite & $-6.3 \pm 0.3$ & $1.039 \pm 0.002$ & ND & ND \\
\hline Goethite $\mathrm{pH} 7$ & $-7.7 \pm 0.4$ & $1.049 \pm 0.001$ & ND & ND \\
\hline Goethite $\mathrm{pH} 7.5$ & $-7.3 \pm 0.3$ & $1.046 \pm 0.002$ & ND & ND \\
\hline Goethite $\mathrm{pH}$ 7.5-NOM & $-6.3 \pm 0.6$ & $1.039 \pm 0.003$ & ND & ND \\
\hline TAFB soil & $-7.9 \pm 0.4$ & $1.049 \pm 0.002$ & ND & ND \\
\hline TCAAP sediment & $-8.2 \pm 0.2$ & $1.050 \pm 0.001$ & ND & ND \\
\hline Anaerobic biodegradation $^{\mathrm{c}}$ & $-9.9 \pm 0.7$ & $1.063 \pm 0.005$ & $-4.7 \pm 1.1$ & $1.005 \pm 0.001$ \\
\hline Anaerobic biodegradation $^{\mathrm{d}}$ & $-5.0 \pm 0.3$ & $1.031 \pm 0.002$ & $\mathrm{NA}^{\mathrm{g}}$ & NA \\
\hline Aerobic biodegradation ${ }^{\mathrm{e}}$ & $-2.3 \pm 0.5$ & $1.006 \pm 0.003$ & $-0.8 \pm 0.5$ & $1.001 \pm 0.001$ \\
\hline Hydrolysis $^{\mathrm{f}}$ & -5.3 & 1.033 & -7.80 & 1.008 \\
\hline
\end{tabular}

a bulk $\mathrm{N}$ isotope enrichment factor.

${ }^{\mathrm{b}} \mathrm{ND}=$ no data. Analysis for $\mathrm{C}$ was affected by interferences. See SI.

${ }^{\mathrm{c}}$ composited isotope data from RDX anaerobic degradation by multiple anaerobic strains via nitro reduction. ${ }^{17}$

${ }^{\mathrm{d}}$ RDX anaerobic degradation by non-specific sediment strains via nitro reduction. ${ }^{18}$

e composited isotope data from RDX aerobic degradation by multiple anaerobic strains via denitration. ${ }^{17}$

${ }^{\mathrm{f}}$ isotope data from RDX hydrolysis via ring cleavage. ${ }^{26}$

g $\mathrm{NA}=$ data not available

Using CSIA to evaluate RDX transformation in groundwater samples from an ammunition plant 
CSIA was applied to evaluate RDX transformation in seven monitoring wells along Line 800 of a subsurface plume at the IAAAP (Figure S1). Concentrations of RDX ranged from $<0.01 \mu \mathrm{M}$ to $29.3 \mu \mathrm{M}$ and decreased radially from sampling point G- 20 , where the highest value was measured. Samples from only four monitoring wells exceeded concentrations of $0.1 \mu \mathrm{M}$ and were suitable for $\mathrm{N}$ isotope ratio measurements of RDX. These wells also had low dissolved oxygen, consistent with reducing conditions (Table S1). The G-20 sample was assumed as the reference point for CSIA of RDX because of its upstream location along the hydrologic gradient. ${ }^{52,53}$ It is in close proximity to the source of the plume ${ }^{54}$ and coincides with the highest aqueous RDX concentration and smallest $\delta^{15} \mathrm{~N}(+0.66 \%)$. This operational $\delta^{15} \mathrm{~N}_{0}$ is somewhat higher than data from the only study of manufactured RDX, which range from $-17 \%$ to $-4 \%$ o depending on synthesis method and raw materials. ${ }^{47}$ The $\delta^{15} \mathrm{~N}$ of G-20 could reflect some degradation of RDX given the historic concentrations of RDX $>50 \mu \mathrm{M}$ reported for 1990-2000. ${ }^{54}$ Figures $3 \mathrm{a}$ and $\mathrm{b}$ show that decreasing RDX concentrations in the sampling wells considered here also correspond with $\delta^{15} \mathrm{~N}$ values increasing by $\sim 15 \%$. The presence of typical RDX reduction products, MNX, DNX, TNX in concentrations $<1.0 \mu \mathrm{M}$ (Figure 3c) supported the assumption of reductive RDX transformation in the subsurface. 

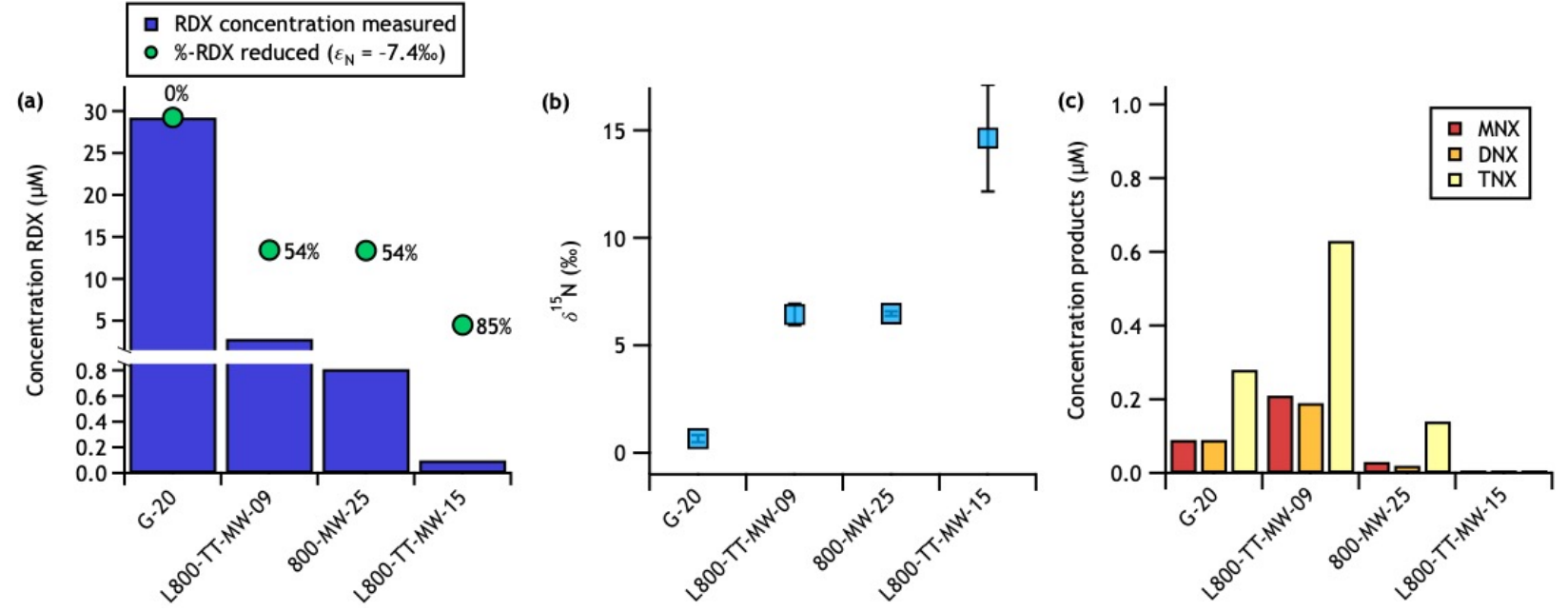

Figure 3. Evaluation of RDX concentrations and $\delta^{15} \mathrm{~N}$ values with regard to reductive transformation in monitoring wells along Line 800 at IAAAP (map see Figure S1). The samples are sorted according to increasing distance from the operationally defined contamination source well G-20. (a) Aqueous concentrations of RDX at different sampling locations including calculated extent of RDX reduction (eq. 6) based on the $\varepsilon_{\mathrm{N}^{-}}$ value obtained in laboratory batch experiments with Fe-minerals. (b) $\delta^{15} \mathrm{~N}$ values of RDX at different sampling locations. (c) Concentrations of partially reduced RDX reduction products.

Based on the detection of RDX reduction products typically associated with abiotic reduction, we evaluated the extent of RDX transformation relative to the $\delta^{15} \mathrm{~N}$ values measured from sampling well G-20 and the average isotope enrichment factor obtained from the batch experiments $\left(\varepsilon_{\mathrm{N}}=-7.4 \%\right.$ ). Figure 3 a shows that calculated RDX concentrations after abiotic reduction with this $\varepsilon_{\mathrm{N}}$-value range between 5 and $15 \mu \mathrm{M}$, compared to measured concentrations of $0.1,0.8$, and $3 \mu \mathrm{M}$. These predicted concentrations correspond to an extent of reductive transformation of $54 \%$ to $85 \%$. If abiotic reduction was the predominant mode of RDX transformation, our data would imply that the measured, lower concentrations were also the consequence of other non-isotope fractionating processes (e.g., sorption, dilution, volatilization). Given that RDX sorption to the solid matrix is likely negligible (see column study below) and 
that RDX is largely non-volatile we hypothesize that the observed decreases in concentration were due to dilution.

\section{CSIA-based evaluation of RDX reduction in sediment columns after ISCR treatment}

The breakthrough of RDX in columns containing TCAAP sediment before and after the first of three dithionite-treatments during ISCR are shown in Figure 4a. RDX retention was only slightly retarded compared to the $\mathrm{NaBr}$ tracer (Figure $\mathrm{S} 5$, retardation factor 1.17), indicating minimal sorption of RDX to the sediment matrix. This observation is consistent with historic field observation of high RDX mobility in the subsurface of contaminated sites. ${ }^{55}$ By contrast, RDX transport through dithionite-treated TCAAP sediment was substantially delayed, with complete breakthrough after 30 pore volumes (Figure 4a). The detection of the RDX reduction products MNX and DNX as well as previous observations of DNAN reduction to phenylenediamine in identical experiments, implies that apparent RDX retardation after the first ISCR cycle was due to reduction by ISCR-generated $\mathrm{Fe}(\mathrm{II})$. Because of the numerous reaction products formed from RDX reduction including ring-cleavage products that were, in part, not detected, no mass or electron balance was computed. The identical behavior of RDX breakthrough was observed after the second ISCR cycle (Figure S6) whereas RDX concentration only reached $60 \%$ of the input concentration after ISCR cycle 3 (see below).

The breakthrough of RDX in sediment columns after ISCR could not be rationalized with the simple reactive transport model described by eqs. 2-5 (Section S8), which assume localized sorption equilibrium and that reduction of RDX leads to the corresponding removal of solidassociated Fe(II). As a simplified means of qualitatively assessing RDX breakthrough behavior, 

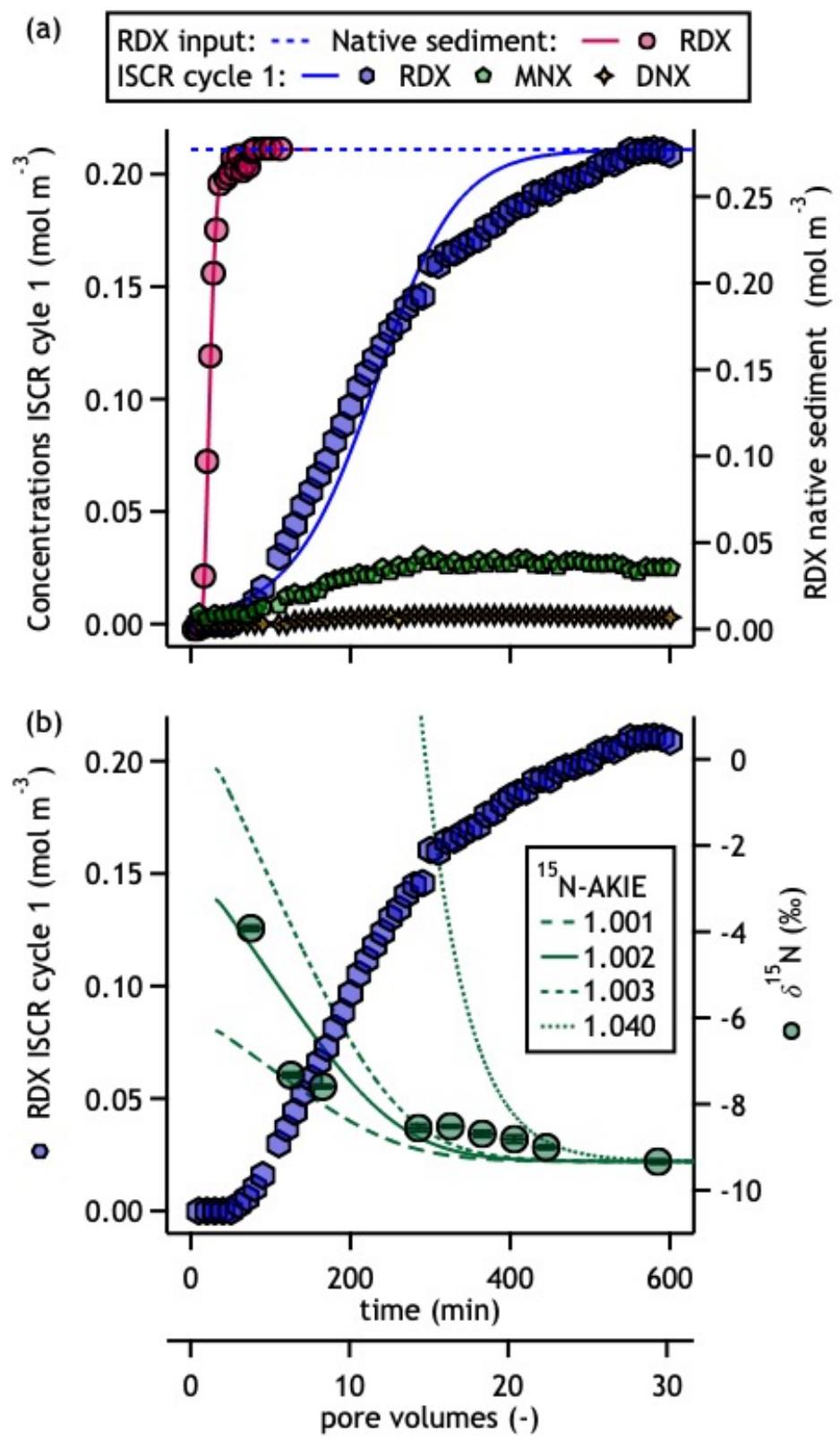

Figure 4 (a) RDX concentrations at the in- and outlet of columns filled with native TCAAP sediment and after the first of three ISCR cycles. Note the different $y$-axes for species concentrations. Solid lines represent calculated RDX breakthrough curves, and calculations for breakthrough following ISCR reflect manipulation of Vred-equiv to account for the observation of apparent overstochiometric removal of Fe(II) by RDX. MNX and TNX were detected only after ISCR. (b) $\delta^{15} \mathrm{~N}$ values and concentrations of RDX measured in the effluent of sediment columns after ISCR. The lines represent the calculated $\delta^{15} \mathrm{~N}$ values of RDX based on parameters listed in Table S3 and different ${ }^{15} \mathrm{~N}$-AKIE values for the abiotic reduction of RDX. The ${ }^{15} \mathrm{~N}$-AKIE value of 1.04 represents the $\mathrm{N}$ isotope fractionation observed during the RDX reduction in batch experiments whereas a value 1.002 reflects the $\mathrm{N}$ isotope fractionation during reactive transport. 
we manipulated the value of $v_{\text {red-equiv }}$ to reflect the observation of apparent highly overstochiometric removal of Fe(II) by RDX (Table S3). This apparent parameter exceeded the known amount of reduction equivalents necessary to transform RDX to TNX by a factor of $>10$ and for complete reduction of all $\mathrm{N}$ from $\mathrm{RDX}$ to ammonia by a factor of $>2.5$ (Table $\mathrm{S} 2$, Figures S7-S12). Based on these observations, we speculate that the oxidation of $\mathrm{Fe}(\mathrm{II})$ by the RDX front caused a limitation of the available $\mathrm{Fe}(\mathrm{II})$ for $\mathrm{RDX}$ reduction due to formation of aggregates of lower hydraulic conductivity, ${ }^{56,57}$ the generation of phases of lower Fe(II) reactivity, ${ }^{58}$ or a combination thereof. No characterization of the column material after the Fe reduction/reoxidation cycles was performed.

The measured $\delta^{15} \mathrm{~N}$ values of RDX at the column outlet after ISCR cycles 1 and 2 are shown in Figures $4 \mathrm{~b}$ and $\mathrm{S} 13 . \delta^{15} \mathrm{~N}$ values of RDX were between $-4 \%$ to $-7 \%$ at early stages of the breakthrough because RDX was only partially reduced. $\delta^{15} \mathrm{~N}$ of RDX reached its original value of $-9.5 \%$ once the RDX outlet and input concentrations matched. The extent of $\mathrm{N}$ isotope fractionation ( $\sim 5 \%)$ observed in column experiments was substantially smaller than expected based on the isotope enrichment factors and AKIEs determined in batch experiments as well as that observed at IAAAP groundwater sampling wells $(\sim 15 \%)$. The lines in Figure $4 \mathrm{~b}$ show the calculated $\delta^{15} \mathrm{~N}$ of RDX based on assumptions for different ${ }^{15} \mathrm{~N}$-AKIEs. An AKIE of 1.04 would correspond to the $\mathrm{N}$ isotope fractionation observed in batch experiments. Instead, we find a 20fold smaller fractionation as expressed by a ${ }^{15} \mathrm{~N}$-AKIE of 1.002 that would best describe our data. This observation, as well as evidence for limited accessibility of RDX to Fe(II) described above, are consistent with substantially masked $\mathrm{N}$ isotope fractionation. Modeling approaches incorporating corrections to enrichment factors for potential mass transfer limitations, as 
demonstrated for diffusion-dominated vapor phase transport, ${ }^{59}$ could potentially offer improved interpretation of observed masking. We maintain, however, that our simplified modeling approach is justified, considering that the column experiments are just one facet to the much broader scope of this study.

\section{Environmental Implications}

Results from our laboratory experiments show that abiotic reduction mediated by various iron minerals with $\mathrm{Fe}(\mathrm{II})$ gives rise to consistent patterns of $\mathrm{N}$ isotope fractionation of $\mathrm{RDX}$ due to large ${ }^{15} \mathrm{~N}$ kinetic isotope effects, which often exceed those observed for the same reactions of nitroaromatic compounds. These large isotope effects have two practical consequences. First, shifts of $\delta^{15} \mathrm{~N}$ in RDX can be large as observed in the RDX contaminant plume at the Iowa Army Ammunition Plant. This is consistent with similar extents of $\mathrm{N}$ isotope fractionation reported for RDX and other nitro-containing explosives such as TNT and DNT at other contaminated sites. ${ }^{16,33}$ Second, large $\varepsilon_{\mathrm{N}}$ values, such as those reported for reductive RDX transformations, lead to conservative estimates of the fractional amount of contaminant conversion. Together with previous evaluations of isotope fractionation associated with biological RDX transformation under anaerobic and aerobic conditions, ${ }^{17,18,26,28}$ our work contributes to an assessment of the relevant RDX degradation pathways via CSIA on the basis of well-defined isotopic enrichment factors.

Experiments in a flow-through dithionite-treated sediment column point to a potential masking of strongly isotope fractionating reactions. The experimental conditions applied to study the RDX breakthrough, namely high RDX concentration pulses to exhaust the available reduction 
equivalents, are likely not representative of contaminant-to-reductant ratios in the subsurface. Nevertheless, our data imply that application of CSIA to assess RDX reduction after redoxmanipulation requires further scrutiny to provide equally realistic estimates of transformations as found for DNAN in identical systems. ${ }^{20}$ This issue is aggravated by the frequently observed challenges of determining ${ }^{13} \mathrm{C} /{ }^{12} \mathrm{C}$ ratios of RDX reliably by CSIA ${ }^{17,26,33}$ that, contrary to CSIA studies for many other subsurface contaminants, makes the identification of RDX reaction pathways through multi-element isotope analysis particularly challenging.

\section{Acknowledgments}

This work was supported by the Strategic Environmental Research and Development Program (SERDP, Project No. ER 2618). We thank Stephanie Park and Kim-Lee Yarberry at Jacobs Engineering for coordinating groundwater sampling at IAAAP and providing the relevant data for these samples.

\section{Supporting Information}

Supporting information (SI) available: A detailed report of materials, additional analytical methods, sampling, modeling approaches, kinetics information, and further isotope results.

\section{Competing Interests}

The authors declare no competing interests.

\section{References}

(1) Spain, J. C.; Hughes, J. B.; Knackmuss, H. J. Biodegradation of Nitroaromatic 
Compounds and Explosives; CRC Press, 2000. https://doi.org/10.1201/9781420032673.

(2) Albright, R. Cleanup of Chemical and Explosive Munitions; Elsevier Inc., 2012. https://doi.org/10.1016/C2010-0-67036-2.

(3) Talmage, S. S.; Opresko, D. M.; Maxwell, C. J.; Welsh, C. J. E.; Cretella, F. M.; Reno, P. H.; Daniel, F. B.; Contents. Nitroaromatic Munition Compounds: Environmental Effects and Screening Values. Rev. Environ. Contam. Toxicol. 1999, 161, 1-156.

(4) US Environmental Protection Agency. Technical Fact Sheet - Hexahydro-1,3,5Trinitro1,3,5-Triazine (RDX); EPA 505-F-17-008; 2017.

(5) Sunahara, G. I.; Lotufo, G.; Kuperman, R. G.; Hawari, J. Ecotoxicology of Explosives; CRC Press, 2009. https://doi.org/10.1201/9781420004342.

(6) Haas, R.; Schreiber, I.; v. Löw, E.; Stork, G. Conception for the Investigation of Contaminated Munition Plants - 2. Investigation of Former RDX-Plants and Filling Stations. Fresenius. J. Anal. Chem. 1990, 338 (1), 41-45. https://doi.org/10.1007/BF00322782.

(7) Sheremata, T. W.; Halasz, A.; Paquet, L.; Thiboutot, S.; Ampleman, G.; Hawari, J. The Fate of the Cyclic Nitramine Explosive RDX in Natural Soil. Environ. Sci. Technol. 2001, 35 (6), 1037-1040. https://doi.org/10.1021/es001389t.

(8) Binks, P. R.; Nicklin, S.; Bruce, N. C. Degradation of Hexahydro-1,3,5-Trinitro-1,3,5Triazine (RDX) by Stenotrophomonas Maltophilia PB1. 1995, 61 (4), 1318-1322.

(9) Lustgarten, A. Open burns, ill winds https://www.propublica.org/article/militarypollution-open-burns-radford-virginia (accessed Nov 24, 2020).

(10) Spalding, R. O. Y. F.; Fulton, J. W. Groundwater Munition Residues and Nitrate near Grand Island, Nebraska, U.S.A. 1988, 2, 139-153. 
(11) Jenkins, T. F.; Pennington, J. C.; Ranney, T. A.; Jr, T. E. B.; Miyares, P. H.; Walsh, M. E.; Hewitt, A. D.; Perron, N. M.; Parker, L. V; Hayes, C. A.; et al. Characterization of Explosives Contamination at Military Firing Ranges; ERDC TR-01-5; 2001.

(12) Zhang, B.; Freitag, C. M.; Cañas, J. E.; Cheng, Q.; Anderson, T. A. Effects of Hexahydro1,3,5-Trinitro-1,3,5-Triazine (RDX) Metabolites on Cricket (Acheta Domesticus) Survival and Reproductive Success. Environ. Pollut. 2006, 144 (2), 540-544.

https://doi.org/10.1016/j.envpol.2006.01.023.

(13) Zhang, B.; Kendall, R. J.; Anderson, T. A. Toxicity of the Explosive Metabolites Hexahydro-1,3,5-Trinitroso-1,3,5-Triazine (TNX) and Hexahydro-1-Nitroso-3,5-Dinitro1,3,5-Triazine (MNX) to the Earthworm Eisenia Fetida. Chemosphere 2006, 64 (1), 8695. https://doi.org/10.1016/j.chemosphere.2005.11.037.

(14) Sagi-Ben Moshe, S.; Ronen, Z.; Dahan, O.; Bernstein, A.; Weisbrod, N.; Gelman, F.; Adar, E. Isotopic Evidence and Quantification Assessment of in Situ RDX Biodegradation in the Deep Unsaturated Zone. Soil Biol. Biochem. 2010, 42 (8), 1253-1262. https://doi.org/10.1016/j.soilbio.2010.04.011.

(15) Bernstein, A.; Adar, E.; Ronen, Z.; Lowag, H.; Stichler, W.; Meckenstock, R. U. Quantifying RDX Biodegradation in Groundwater Using $\Delta 15 \mathrm{~N}$ Isotope Analysis. $J$. Contam. Hydrol. 2010, 111 (1-4), 25-35. https://doi.org/10.1016/j.jconhyd.2009.10.010.

(16) Wijker, R. S.; Bolotin, J.; F. Nishino, S.; C. Spain, J.; B. Hofstetter, T. Using CompoundSpecific Isotope Analysis to Assess Biodegradation of Nitroaromatic Explosives in the Subsurface. Environ. Sci. Technol. 2013, 47 (13), 6872-6883. https://doi.org/10.1021/es3051845.

(17) Fuller, M. E.; Heraty, L.; Condee, C. W.; Vainberg, S.; Sturchio, N. C.; Hatzinger, P. B. 
Relating Carbon and Nitrogen Isotope Effects to Reaction Mechanisms during Aerobic or Anaerobic Degradation of RDX (Hexahydro-1,3,5- Trinitro-1,3,5-Triazine) by Pure Bacterial Cultures. Appl. Environ. Microbiol. 2016, 82 (11), 3297-3309. https://doi.org/10.1128/AEM.00073-16.Editor.

(18) Bernstein, A.; Ronen, Z.; Adar, E.; Nativ, R.; Lowag, H.; Stichler, W.; Meckenstock, R. U. Compound-Specific Isotope Analysis of RDX and Stable Isotope Fractionation during Aerobic and Anaerobic Biodegradation. Environ. Sci. Technol. 2008, 42 (21), 7772-7777. https://doi.org/10.1021/es8005942.

(19) Berens, M. J.; Ulrich, B. A.; Strehlau, J. H.; Hofstetter, T. B.; Arnold, W. A. Mineral Identity, Natural Organic Matter, and Repeated Contaminant Exposures Do Not Affect the Carbon and Nitrogen Isotope Fractionation of 2,4-Dinitroanisole during Abiotic Reduction. Environ. Sci. Process. Impacts 2019, 21 (1), 51-62. https://doi.org/10.1039/c8em00381e.

(20) Berens, M. J.; Hofstetter, T. B.; Bolotin, J.; Arnold, W. A. Assessment of 2,4Dinitroanisole Transformation Using Compound-Specific Isotope Analysis after In Situ Chemical Reduction of Iron Oxides. Environ. Sci. Technol. 2020, 54 (9), 5520-5531. https://doi.org/10.1021/acs.est.9b07616.

(21) Pati, S. G.; Shin, K.; Skarpeli-Liati, M.; Bolotin, J.; Eustis, S. N.; Spain, J. C.; Hofstetter, T. B. Carbon and Nitrogen Isotope Effects Associated with the Dioxygenation of Aniline and Diphenylamine. Environ. Sci. Technol. 2012, 46 (21), 11844-11853. https://doi.org/10.1021/es303043t.

(22) Hofstetter, T. B.; Schwarzenbach, R. P.; Bernasconi, S. M. Assessing Transformation Processes of Organic Compounds Using Stable Isotope Fractionation. Environ. Sci. 
Technol. 2008, 42 (21), 7737-7743. https://doi.org/10.1021/es801384j.

(23) Wijker, R. S.; Kurt, Z.; Spain, J. C.; Bolotin, J.; Zeyer, J.; B. Hofstetter, T. Isotope Fractionation Associated with the Biodegradation of 2- and 4-Nitrophenols via Monooxygenation Pathways. Environ. Sci. Technol. 2013, 47 (24), 14185-14193. https://doi.org/10.1021/es403876u.

(24) Hofstetter, T. B.; Schwarzenbach, R. P.; Haderlein, S. B. Reactivity of Fe(II) Species Associated with Clay Minerals. Environ. Sci. Technol. 2003, 37 (3), 519-528. https://doi.org/10.1021/es025955r.

(25) Hofstetter, T. B.; Bolotin, J.; Pati, S. G.; Skarpeli-Liati, M.; Spahr, S.; Wijker, R. S. Isotope Effects as New Proxies for Organic Pollutant Transformation. Chimia (Aarau). 2014, 68 (11), 788-792. https://doi.org/10.2533/chimia.2014.788.

(26) Gelman, F.; Kotlyar, A.; Chiguala, D.; Ronen, Z. Precise and Accurate CompoundSpecific Carbon and Nitrogen Isotope Analysis of RDX by GC-IRMS. Int. J. Environ. Anal. Chem. 2011, 91 (14), 1392-1400. https://doi.org/10.1080/03067319.2010.484888.

(27) Halasz, A.; Hawari, J. Degradation Routes of RDX in Various Redox Systems. In ACS Symposium Series; American Chemical Society, 2011; Vol. 1071, pp 441-462. https://doi.org/10.1021/bk-2011-1071.ch020.

(28) Bernstein, A.; Ronen, Z.; Gelman, F. Insight on RDX Degradation Mechanism by Rhodococcus Strains Using 13C and 15N Kinetic Isotope Effects. Environ. Sci. Technol. 2013, 47 (1), 479-484. https://doi.org/10.1021/es302691g.

(29) Fuller, M. E.; McClay, K.; Hawari, J.; Paquet, L.; Malone, T. E.; Fox, B. G.; Steffan, R. J. Transformation of RDX and Other Energetic Compounds by Xenobiotic Reductases XenA and XenB. Appl. Microbiol. Biotechnol. 2009, 84 (3), 535-544. 
https://doi.org/10.1007/s00253-009-2024-6.

(30) Halasz, A.; Manno, D.; Strand, S. E.; Bruce, N. C.; Hawari, J. Biodegradation of RDX and MNX with Rhodococcus Sp. Strain DN22: New Insights into the Degradation Pathway. Environ. Sci. Technol. 2010, 44 (24), 9330-9336. https://doi.org/10.1021/es1023724.

(31) Larese-Casanova, P.; Scherer, M. M. Abiotic Transformation of Hexahydro-1,3,5-Triazine (RDX) by Green Rust. Environ. Sci. Technol. 2008, 42 (11), 3795-3981. https://doi.org/10.1021/es702390b.

(32) Hoffsommer, J. C.; Kubose, D. A.; Glover, D. J. Kinetic Isotope Effects and Intermediate Formation for the Aqueous Alkaline Homogeneous Hydrolysis of 1,3,5-Triaza-1,3,5Trinitrocyclohexane (RDX). J. Phys. Chem. 1977, 81 (5), 380-385. https://doi.org/10.1021/j100520a003.

(33) Fuller, M. E.; Koster van Groos, P. G.; Jarrett, M.; Kucharzyk, K. H.; Minard-Smith, A.; Heraty, L. J.; Sturchio, N. C. Application of a Multiple Lines of Evidence Approach to Document Natural Attenuation of Hexahydro-1,3,5-Trinitro-1,3,5-Triazine (RDX) in Groundwater. Chemosphere 2020, 250, 126210. https://doi.org/10.1016/j.chemosphere.2020.126210.

(34) Khatiwada, R.; Root, R. A.; Abrell, L.; Sierra-Alvarez, R.; Field, J. A.; Chorover, J. Abiotic Reduction of Insensitive Munition Compounds by Sulfate Green Rust. Environ. Chem. 2018, 15 (5), 259-266. https://doi.org/10.1071/EN17221.

(35) Gregory, K. B.; Larese-Casanova, P.; Parkin, G. F.; Scherer, M. M. Abiotic Transformation of Hexahydro-1,3,5-Trinito-1,3,5-Triazine by Fe II Bound to Magnetite. Environ. Sci. Technol. 2004, 38 (5), 1408-1414. https://doi.org/10.1021/es034588w.

(36) Boparai, H. K.; Comfort, S. D.; Shea, P. J.; Szecsody, J. E. Remediating Explosive- 
Contaminated Groundwater by in Situ Redox Manipulation (ISRM) of Aquifer Sediments.

Chemosphere 2008. https://doi.org/10.1016/j.chemosphere.2007.11.001.

(37) Tobler, N. B.; Hofstetter, T. B.; Straub, K. L.; Fontana, D.; Schwarzenbach, R. P. IronMediated Microbial Oxidation and Abiotic Reduction of Organic Contaminants under Anoxic Conditions. Environ. Sci. Technol. 2007, 41 (22), 7765-7772. https://doi.org/10.1021/es071128k.

(38) Gorski, C. A.; Nurmi, J. T.; Tratnyek, P. G.; Hofstetter, T. B.; Scherer, M. M. Redox Behavior of Magnetite: Implications for Contaminant Reduction. Environ. Sci. Technol. 2010, 44, 55-60. https://doi.org/10.1021/es9016848.

(39) Hofstetter, T. B.; Neumann, A.; Arnold, W. A.; Hartenbach, A. E.; Bolotin, J.; Cramer, C. J.; Schwarzenbach, R. P. Substituent Effects on Nitrogen Isotope Fractionation during Abiotic Reduction of Nitroaromatic Compounds. Environ. Sci. Technol. 2008, 42 (6), 1997-2003. https://doi.org/10.1021/es702471k.

(40) Hartenbach, A.; Hofstetter, T. B.; Berg, M.; Bolotin, J.; Schwarzenbach, R. P. Using Nitrogen Isotope Fractionation to Assess Abiotic Reduction of Nitroaromatic Compounds. Environ. Sci. Technol. 2006, 40 (24), 7710-7716. https://doi.org/10.1021/es061074z.

(41) Cárdenas-Hernández, P. A.; Anderson, K. A.; Murillo-Gelvez, J.; Di Toro, D. M.; Allen, H. E.; Carbonaro, R. F.; Chiu, P. C. Reduction of 3-Nitro-1,2,4-Triazol-5-One (NTO) by the Hematite-Aqueous Fe(II) Redox Couple. Environ. Sci. Technol. 2020, 54 (19), 1219112201. https://doi.org/10.1021/acs.est.0c03872.

(42) Strehlau, J. H.; Berens, M. J.; Arnold, W. A. Mineralogy and Buffer Identity Effects on RDX Kinetics and Intermediates during Reaction with Natural and Synthetic Magnetite. Chemosphere 2018, 213, 602-609. https://doi.org/10.1016/j.chemosphere.2018.09.139. 
(43) Viollier, E.; Inglett, P. W.; Hunter, K.; Roychoudhury, A. N.; Cappellen, P. Van. The Ferrozine Method Revisited: Fe(II)/Fe(III) Determination in Natural Waters. 2014, 15, 16.

(44) Soman, A.; Qiu, Y.; Chan, L. Q. HPLC-UV Method Development and Validation for the Determination of Low Level Formaldehyde in a Drug Substance. J. Chromatogr. Sci. 2008, 46 (6), 461-465. https://doi.org/10.1093/chromsci/46.6.461.

(45) Taylor, B. W.; Keep, C. F.; Hall, R. O.; Koch, B. J.; Tronstad, L. M.; Flecker, A. S.; Ulseth, A. J. Improving the Fluorometric Ammonium Method: Matrix Effects, Background Fluorescence, and Standard Additions. J. North Am. Benthol. Soc. 2007, 26 (2), 167-177. https://doi.org/10.1899/0887-3593(2007)26[167:ITFAMM]2.0.CO;2.

(46) Jochmann, M. A.; Blessing, M.; Haderlein, S. B.; Schmidt, T. C. A New Approach to Determine Method Detection Limits for Compound-Specific Isotope Analysis of Volatile Organic Compounds. Rapid Commun. Mass Spectrom. 2006, 20 (24), 3639-3648. https://doi.org/10.1002/rcm.2784.

(47) Howa, J. D.; Lott, M. J.; Chesson, L. A.; Ehleringer, J. R. Carbon and Nitrogen Isotope Ratios of Factory-Produced RDX and HMX. Forensic Sci. Int. 2014, 240 (2014), 80-87. https://doi.org/10.1016/j.forsciint.2014.04.013.

(48) Reichert, P. Aquasim - A Tool for Simulation and Data Analysis of Aquatic Systems. In Water Science and Technology; Pergamon Press Inc, 1994; Vol. 30, pp 21-30. https://doi.org/10.2166/wst.1994.0025.

(49) Stewart, S. M.; Hofstetter, T. B.; Joshi, P.; Gorski, C. A. Linking Thermodynamics to Pollutant Reduction Kinetics by $\mathrm{Fe}^{2+}$ Bound to Iron Oxides. Environ. Sci. Technol. 2018, acs.est.8b00481. https://doi.org/10.1021/acs.est.8b00481. 
(50) Strehlau, J. H.; Stemig, M. S.; Penn, R. L.; Arnold, W. A. Facet-Dependent Oxidative Goethite Growth As a Function of Aqueous Solution Conditions. Environ. Sci. Technol. 2016, 50 (19), 10406-10412. https://doi.org/10.1021/acs.est.6b02436.

(51) Strehlau, J. H.; Schultz, J. D.; Vindedahl, A. M.; Arnold, W. A.; Penn, R. L. Effect of Nonreactive Kaolinite on 4-Chloronitrobenzene Reduction by Fe(Ii) in Goethite-Kaolinite Heterogeneous Suspensions. Environ. Sci. Nano 2017, 4 (2), 325-334. https://doi.org/10.1039/c6en00469e.

(52) Hunkeler, D.; Meckenstock, R. U.; Lollar, B. S.; Schmidt, T. C.; Wilson, J. T. A Guide for Assessing Biodegradation and Source Identification of Organic Ground Water Contaminants Using Compound Specific Isotope Analysis (CSIA). U.S. Environ. Prot. Agency 2008, EPA/600/R-(December), 1-82.

(53) Sherwood Lollar, B.; Slater, G. F.; Sleep, B.; Witt, M.; Klecka, G. M.; Harkness, M.; Spivack, J. Stable Carbon Isotope Evidence for Intrinsic Bioremediation of Tetrachloroethene and Trichloroethene at Area 6, Dover Air Force Base. Environ. Sci. Technol. 2001, 35 (2), 261-269. https://doi.org/10.1021/es001227x.

(54) Engineers, U. A. C. of. Groundwater Flow and Contaminant Fate and Transport Modeling Line 800 Pink Water Lagoon, Iowa Army Ammunitin Plant, Middletown, Iowa https://www.iaaaprestoration.com/wp-content/uploads/345-RIL800PWLGWFlowandContaminantFateTechMemo-FEB2003.pdf (accessed Nov 24, 2020).

(55) Spalding, R. F.; Fulton, J. W. Groundwater Munition Residues and Nitrate near Grand Island, Nebraska, U.S.A. J. Contam. Hydrol. 1988, 2 (2), 139-153. https://doi.org/10.1016/0169-7722(88)90004-6. 
(56) Liu, H.; Bruton, T. A.; Doyle, F. M.; Sedlak, D. L. In Situ Chemical Oxidation of Contaminated Groundwater by Persulfate: Decomposition by Fe(III)- and Mn(IV)Containing Oxides and Aquifer Materials. Environ. Sci. Technol. 2014, 48 (17), 1033010336. https://doi.org/10.1021/es502056d.

(57) Kretzschmar, R.; Borkovec, M.; Grolimund, D.; Elimelech, M. Mobile Subsurface Colloids and Their Role in Contaminant Transport. Adv. Agron. 1999, 66 (C), 121-193. https://doi.org/10.1016/S0065-2113(08)60427-7.

(58) Elsner, M.; Schwarzenbach, R. P.; Haderlein, S. B. Reactivity of Fe(II)-Bearing Minerals toward Reductive Transformation of Organic Contaminants. Environ. Sci. Technol. 2004, 38 (3), 799-807. https://doi.org/10.1021/es0345569.

(59) Khan, A. M.; Wick, L. Y.; Thullner, M. Applying the Rayleigh Approach for Stable Isotope-Based Analysis of VOC Biodegradation in Diffusion-Dominated Systems. Environ. Sci. Technol. 2018, 52 (14), 7785-7795. https://doi.org/10.1021/acs.est.8b01757. 